\title{
Leptin Gene Expression in Rabbits During Pregnancy and Fetal Life
}

\author{
Doaa Kirat ${ }^{1}$, Nora E. Abdel Hamid ${ }^{1}$, Wafaa E. Mohamed ${ }^{1}$, Mohamed Hamada ${ }^{1} \&$ Shimaa I. Shalaby ${ }^{1}$ \\ ${ }^{1}$ Department of Physiology, Faculty of Veterinary Medicine, Zagazig University, Zagazig, Egypt \\ Correspondence: Doaa Kirat, Department of Physiology, Faculty of Veterinary Medicine, Zagazig University, \\ Zagazig, Egypt. Tel: 20-055-228-4283. E-mail: doaakirat@hotmail.com
}

Received: February 9, 2015 Accepted: February 26, 2015 Online Published: March 17, 2015

doi:10.5539/ijb.v7n2p113

URL: http://dx.doi.org/10.5539/ijb.v7n2p113

\begin{abstract}
Leptin may act as the critical link between adipose tissue and reproduction. Although considerable progress has been achieved in understanding the reproductive actions of leptin, much work is needed for understanding its physiological role. Till now, no data has been published about the distribution and expression levels of leptin in the rabbit maternal adipose tissue, placenta, and various fetal rabbit tissues during pregnancy and postpartum. Our results indicated that circulating leptin levels in rabbit serum during pregnancy were significantly higher than in postpartum and non pregnant rabbits. Furthermore, leptin showed positive correlations with body weight and estrogen and negative correlation with progesterone in pregnant and postpartum rabbits. RT-PCR verified the presence of RNAs encoding leptin in the rabbit maternal perirenal adipose tissue, placenta, and several fetal tissues; including brain, liver, adipose tissue, and bone. The relative abundance of leptin RNA in rabbit maternal adipose was significantly higher at $20^{\text {th }}$ day of pregnancy than that of non pregnant rabbits, while it was significantly decreased at $2^{\text {nd }}$ day after parturition. No significant changes in the placental leptin RNA levels were noticed in pregnant rabbits at $10^{\text {th }}, 20^{\text {th }}$, and $30^{\text {th }}$ day of pregnancy. The relative abundance of fetal leptin transcripts at day $30^{\text {th }}$ of pregnancy was in the order of liver $>$ bone $\geq$ adipose tissue $>$ brain. The present study provides new evidence for the distribution and expression levels of leptin in the rabbit maternal and fetal tissues during pregnancy and supports the importance of leptin in reproductive physiology and fetal development.
\end{abstract}

Keywords: leptin, steroids, pregnancy, fetus, rabbit

\section{Introduction}

Leptin is a 16-kDa cytokine encoded by the obese gene and primarily secreted by adipocytes (Zhang et al., 1994). Leptin, upon binding to specific receptors in different areas of the hypothalamus, is involved in the control of body weight through its effects on food intake and energy expenditure by negative feedback at the hypothalamic nuclei (Zhang et al., 1994). Leptin plays critical actions in the development (Hoggard et al., 1997) and haemopoiesis (Gainsford et al., 1996). Giving that leptin is a pleiotropic and ubiquitous molecule; it has been implicated in several key points of the mammalian reproductive functions such as ovulation (Cunningham et al., 1999), and pregnancy (Mounzih et al., 1998). In particular, leptin may act as the critical link between adipose tissue and the reproductive system, indicating whether adequate energy reserves are present for normal reproductive function. Although considerable progress has been achieved in understanding the reproductive actions of leptin over the past few years, much work is needed before we can arrive at a complete understanding of its physiological role, if any.

In fact, leptin has been identified in the adult human (Butte et al., 1997) and rat (Kawai et al., 1997), mouse (Tomimatsu et al., 1997).

In rabbits, leptin receptor (Ob-R) has been detected in endometrial cells (Gonzalez \& Leavis, 2003) and the ovary at day 9 of pseudo-pregnancy by immunohistochemistry and Western blot analysis that supports a permissive luteolytic role for leptin in rabbit Corpus luteum (Zerani et al., 2004). Recently, Koch et al. (2013) identified the leptin gene cloning and expression in the rabbit mammary epithelial cells during pregnancy and lactation. Up till now, no data has been published concerning the expression and distribution of leptin in the rabbit adipose tissue and placenta as well as the different fetal rabbit tissues.

Pregnancy is a hyper metabolic state in which a great increase in maternal body fat and weight occurs and associated with relevant endocrine changes. In addition, energy needs are increased during pregnancy. These 
increased energy needs may be met through partitioning of nutrients for energy utilization which is under hormonal control. Therefore, in order to verify to what degree pregnancy influences leptin in rabbits, we intended to measure the leptin hormone in the blood and estimate its in vivo expression level in the maternal adipose tissue and placenta at different stages of pregnancy in rabbits. Moreover, to assess whether leptin is involved in the rabbit fetal growth and development, we aimed to investigate the expression level and distribution of RNAs encoding leptin in the 10-day post-coitus rabbit fetus and in various fetal tissues using reverse transcription-PCR.

Moreover, to ascertain the relationship between serum leptin levels and related variables (body weight and steroids in rabbits), the present study also aimed to gain a comprehensive view of leptin correlations with body weight, estrogen, and progesterone in pregnant and non pregnant control rabbits.

\section{Materials and Methods}

\subsection{Animals and Experimental Designs}

A total of 30 sexually mature healthy New Zealand White female rabbits weigh between 2600-3200 g and of $\sim 6$ months old were used. Rabbits were housed in individual stainless steel cages provided with automatic drinkers. All rabbits were raised on balanced diet (20\% protein, $2.62 \%$ fat, $11 \%$ fiber, and $2600 \mathrm{kcal} / \mathrm{kg}$ energy). Rabbits were housed in an animal room which maintained on a 12-h light-dark cycle at an ambient temperature of $25 \pm 2$ ${ }^{\circ} \mathrm{C}$ and $35-50 \%$ humidity for two weeks before starting the experiment for adaptation.

After quarantine period, rabbits were distributed into two groups; the control group (6 rabbits) which represent the non pregnant rabbits and the experimental group ( 24 rabbits) that were introduced into the male's cages. The mated ratio is identically one male one female (for mating on a 1:1 basis). The female was considered mated when the sperms were found in the vaginal washing and that day was designed the first day of pregnancy. It was expected that a female would give birth 30 days following an observed copulatory episode. These mated rabbits were divided equally into 4 groups ( 6 rabbits each) which designated at pregnancy day 10, 20, 30, and after parturition. The experimental protocol used in the present study was approved by the Laboratory Animal Control Guidelines of Faculty of Veterinary Medicine, Zagazig University.

\subsection{Blood and Tissue Samples}

Blood samples were collected during sacrifying the rabbits in each group into sterile test tubes without anticoagulant. For serum collection, samples were kept at room temperature for $30 \mathrm{~min}$, and then centrifuged at $3000 \mathrm{rpm}$ for $15 \mathrm{~min}$. The serum samples were stored at $-20^{\circ} \mathrm{C}$ until used for hormone analysis.

After scarifying on days 10,20, and 30 of pregnancy as well as days 2 and 7 after parturition, tissue samples from the maternal perirenal adipose tissue and placenta as well as different fetal tissues such as (brain, liver, bone, and perirenal adipose tissue) were immediately collected from the rabbits and washed in ice-cold $0.9 \%$ $(\mathrm{w} / \mathrm{v}) \mathrm{NaCl}$. These tissue samples were immediately snap-frozen in liquid nitrogen and subsequently stored at $-80^{\circ} \mathrm{C}$ until use for RT-PCR analysis.

\subsection{Hormonal Analysis}

Serum leptin was measured using DRG Leptin ELISA kit (DRG Instruments GbH, Germany) according to the manufacturer protocol.

Serum estradiol II $\left(\mathrm{E}_{2}\right)$ level was determined using electrochemiluminescence immunoassay (ECLIA) kit (Catalog Number: 03000079190, Roche Diagnostics, North America) and measured by cobas e 411 immunoassay analyzer according to the manufacturer instructions.

Serum progesterone level was determined using electrochemiluminescence immunoassay (ECLIA) kit (Catalog Number: 12145383160, Roche Diagnostics, North America) and measured by cobas e 411 analyzer according to the manufacturer instructions.

\subsection{Molecular Analysis}

Leptin gene expression was determined in the female and fetal rabbit's tissues by using the semi-quantitative RT-PCR.

\subsubsection{Total RNA Isolation}

RNA was isolated from the tissue samples by using Easy-RED ${ }^{\mathrm{TM}}$ Total RNA Extraction Kit (iNtRON Cat. No. 17063) following the manufacturer instructions. 


\subsubsection{Reverse Transcription}

Total RNA (5 ug per sample) was reverse transcribed into cDNA using Revert Aid h minus reverse transcriptase (Fermentas, \#EP0451, Thermofisher Scientific, European Union) and a mix of oligo (dT) (0.5 ug/reaction, 4 ul $5 \mathrm{x}$ reaction buffer, $0.5 \mathrm{ug}$ RNase inhibitor, and 2 ul deoxynucleotide triphosphate (dNTP) mix) in a $12.5 \mathrm{ul}$ total reaction volume at $42^{\circ} \mathrm{C}$ for $60 \mathrm{~min}$. To terminate the reaction, the tubes were heated at $70^{\circ} \mathrm{C}$ for $10 \mathrm{~min}$ and then stored at $-80^{\circ} \mathrm{C}$.

\subsubsection{Polymerase Chain Reaction (PCR)}

The specific oligonucleotide primers used for PCR to amplify the leptin gene were designed using primer 3.0 software (http://www-genome.wi.mit.edu/cgi-bin/primer/primer3_www.cgi) based on the published leptin sequences of rabbits (GenBank accession no. 001163069.1) (Zhao \& Wu, 2005). The forward primer was 5'-GTCGTCGGTTTGGACTTCATC-3' and the reverse primer was 5'-CGGAGGTTCTCCAGGTCGTTG-3'. As a control, PCR amplification with a pair of GAPDH primers based on published sequences with GenBank accession number 001082253.1 (The forward primer 5'-GGAGCCAAAAGGGTCATC-3' and reverse primer 5'-CCAGTGAGTTTCCCGTTC-3') were used. The oligonucleotide primers were synthesized by Metabion International AG, Planegg/Martinsried, Germany.

The isolated cDNA were amplified using Maximo Taq DNA Polymerase 2X-preMix kit (GeneOn GbH, Deutschland, Germany) following the manufacturer protocol. In brief, the PCR was carried out in a reaction volume of $50 \mu$, containing $3.0 \mathrm{ul}$ cDNA template $(50 \mathrm{ng}), 25 \mathrm{ul} 2 \mathrm{x}$ Taq master mix, $0.5 \mathrm{ul}(10 \mu \mathrm{M})$ forward primer, $0.5 \mathrm{ul}(10 \mu \mathrm{M})$ reverse primer, and $21 \mathrm{ul}$ sterile nuclease free water. The thermal cycling parameters were an initial denaturation at $94^{\circ} \mathrm{C}$ for $3 \mathrm{~min}, 38$ cycles of amplification in a Techne, TC-3000 thermal cycler (Bibby Scientific Ltd, Staffordshire, UK) were performed under the following conditions: $94^{\circ} \mathrm{C}$ for $1 \mathrm{~min}, 55-60^{\circ} \mathrm{C}$ for $1 \mathrm{~min}$, and $72^{\circ} \mathrm{C}$ for $80 \mathrm{sec}$ followed by a final extension at $72^{\circ} \mathrm{C}$ for $10 \mathrm{~min}$.

The PCR products (146 and 346 bp for leptin and GAPDH, respectively) were electrophoresed on 1.5\% agarose gel, stained by ethidiumbromide, and visualized under UV light. The amplified RT-PCR products were cloned into pSTBlue-1 Accep-Tor Vector (Novagen, Darmstadt, Germany) followed by sequencing with the BigDye Terminator v3.1 Cycle Sequencing kit (Applied BioSystems, Foster City, Calif., USA), according to the manufacturer's instructions, in an ABI Prism 3100 automated sequencer (Applied Biosystems). Homology searches of the cDNA sequences were carried out against previously identified genes by using the Basic Local Alignment Search Tool (BLASTx) program (http://www.ncbi.nlm.nih.gov/blast/ Blast.cgi) of the GenBank database (National Center for Biotechnology Information, Washington, D.C., USA).

The relative abundance of leptin RNA was normalized with respect GABDH. Densitometric analysis for the leptin bands was quantified using ImageJ gel analysis program (NIH, Bethseda, MD, USA). (http://rsb.info.nih.gov/ij/index.html).

\subsection{Statistical Analysis}

Results are expressed as means \pm S.E.M. All statistical analyses were performed using one-way analysis of variance (ANOVA) (SPSS 17.0; SPSS, Inc., Chicago, IL, USA) or Duncan's test. The diagrams were drawn by GraphPad Prism 5.0 (GraphPad Software, San Diego, CA, USA). Differences were considered significant at P values $\leq 0.05$. Pearsons correlation (simple linear correlation) was used to measure the correlation values and relationship between two variables (SPSS 17.0; SPSS, Inc., Chicago, IL, USA). Positive correlation is represented by the value +1.00 , no correlation by 0.00 , and negative correlation by -1.00 .

\section{Results and Discussion}

The present study, for the first time, estimated the serum leptin levels in the non-pregnant, pregnant, and lactating rabbits (Figure 1). Additionally, to the best of our knowledge, this is the first report to describe the existence of leptin transcripts in the adipose and placental tissues of rabbits during different pregnancy stages (Figures 4 and 5). Our quantitative RT-PCR data confirmed that leptin expression level in the maternal perirenal adipose tissue during lactation was lower than in pregnancy but higher than non-pregnant rabbits (Figure 4). Our findings, which were similar to those obtained in other species, support a direct role of leptin in the regulation of several reproductive functions. Additionally, the present study demonstrates, for the first time, that leptin gene expression was present in a number of tissues in the fetal rabbits (Figure 6). This expression of leptin in the rabbit fetal tissues suggests that the leptin may be involved in the growth and development of the fetus. Furthermore, the study proved that serum leptin level was correlated positively to the body weight (Figure 3 ) and estrogen (Figure 8), and negatively to progesterone (Figure 10) along the stages examined. 


\subsection{Serum Leptin Levels Throughout Pregnancy and After Parturition in Rabbits}

Figure (1) showed the significant increase in circulating serum leptin level $(2.40 \pm 0.08 \mathrm{ng} / \mathrm{ml}$ and $2.32 \pm 0.04 \mathrm{ng} / \mathrm{ml})$ at $20^{\text {th }}$ and $30^{\text {th }}$ day of pregnancy in rabbits, respectively when compared to the non-pregnant control $(1.88 \pm$ $0.04 \mathrm{ng} / \mathrm{ml}$ ) group. Interestingly, after parturition, the serum leptin level in rabbits was significantly lower, as detected on the $2^{\text {nd }}$ day post-partum $(2.06 \pm 0.02 \mathrm{ng} / \mathrm{ml})$ than that was detected on the $20^{\text {th }}$ and $30^{\text {th }}$ day of pregnancy in rabbits $(2.40 \pm 0.08 \mathrm{ng} / \mathrm{ml}$ and $2.32 \pm 0.04 \mathrm{ng} / \mathrm{ml}$, respectively). Whereas, the serum leptin level after parturition $(2.06 \pm 0.02 \mathrm{ng} / \mathrm{ml})$ was significantly $(\mathrm{P}<0.05)$ higher than that was detected in the non-pregnant rabbits and on the $10^{\text {th }}$ day of pregnancy $(1.88 \pm 0.04 \mathrm{ng} / \mathrm{ml}$ and $1.76 \pm 0.02 \mathrm{ng} / \mathrm{ml}$, respectively). Additionally, it is apparent from the data in Figure (1) that there was no significant changes in serum leptin levels between non pregnant control rabbits $(1.88 \pm 0.04 \mathrm{ng} / \mathrm{ml})$ and at the $10^{\text {th }}$ day of pregnancy $(1.76 \pm 0.02 \mathrm{ng} / \mathrm{ml})$, also there was no significant changes in serum leptin levels between the pregnancy day $20(2.40 \pm 0.08 \mathrm{ng} / \mathrm{ml})$ and $30(2.32 \pm 0.04 \mathrm{ng} / \mathrm{ml})$.

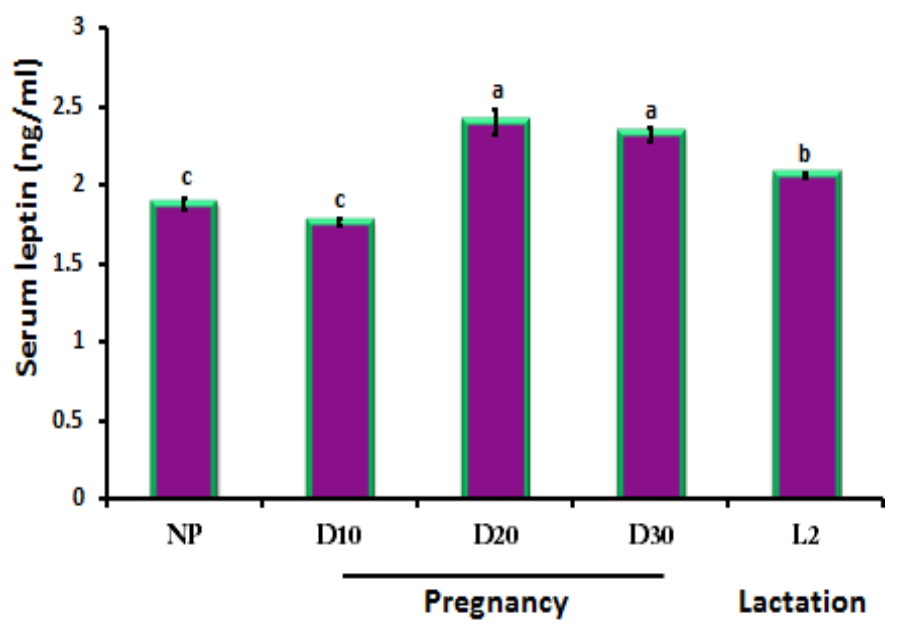

Figure 1. Changes in circulating leptin concentrations during pregnancy and lactation in rabbits. Leptin concentrations $(\mathrm{ng} / \mathrm{ml})$ were measured in the serum samples obtained from rabbits at $10^{\text {th }}, 20^{\text {th }}, 30^{\text {th }}$ day of pregnancy (D10, D20, and D30, respectively), lactation day 2 (L2), and non pregnant (NP). Different letters denote significant differences $(\mathrm{P} \leq 0.05)$. Data are expressed as means \pm S.E.M. of six animals each group

Increased leptin level appears to be a ubiquitous feature of pregnant mammals. Most reports indicate that there were substantial increase occurs in the rat from midgestation, and this is followed by a clear pre-partum decline (Kawai et al., 1997; Amico et al., 1998; Seeber et al., 2002). Additionally, the maternal plasma leptin concentrations remain relatively stable during the first half of rodent pregnancy but then increase dramatically from midgestation in the mouse (Gavrilova et al., 1997; Tomimatsu et al., 1997) and humans (Butte et al., 1997). The high levels of maternal leptin serum throughout pregnancy and its decline drastically postpartum suggests a functional importance of leptin during pregnancy. One study reported, however, that pregnancy induced increases in plasma leptin are not evident if compared to the non pregnant control rats (Terada et al., 1998).

The rise in plasma leptin from mid pregnancy appears due to the combined effects of increased plasma leptin binding activity (Gavrilova et al., 1997; Seeber et al., 2002) and enhanced maternal adipocyte expression of leptin mRNA (Kawai et al., 1997; Tomimatsu et al., 1997). Since leptin is cleared by the kidney, at least partially by filtration (Cumin et al., 1996), binding of the leptin to the binding protein should decrease its clearance. Thus hyperleptinemia during pregnancy is probably due to reduced renal clearance of bound leptin. Nonetheless, the prepartum decline in plasma leptin levels in the rat may reflect reduced fat mass in late pregnancy (Herrera et al., 2000).

\subsection{Correlation Between Leptin Level \& Body Weight During Pregnancy and Lactation in Rabbits}

Gestational weight gain is a unique and complex biological phenomenon that supports the functions of growth and development of the fetus (Gunderson \& Abrams, 2000). Consistent with this concept, the results of the present study (Figure 2) revealed that the body weight in rabbits was significantly increase $(\mathrm{P} \leq 0.05)$ at $30^{\text {th }}$ day of pregnancy $(3150 \pm 220.22 \mathrm{~g})$ in comparison to rabbits at $10^{\text {th }}$ day of pregnancy $(2700 \pm 141.42 \mathrm{~g})$ and the non-pregnant control group (2675 $79.84 \mathrm{~g})$. Moreover, there was significant increase in the body weight of rabbits at $20^{\text {th }}$ day of pregnancy $(2875 \pm 58.09 \mathrm{~g})$ in comparison to the non-pregnant control group $(2675 \pm 79.84$ 
g). Besides, (Figure 2) showed increase in the body weight of pregnant rabbits at $30^{\text {th }}$ day of pregnancy $(3150 \pm 220.22 \mathrm{~g})$ more than that of the $20^{\text {th }}(2875 \pm 58.09 \mathrm{~g})$ day of pregnancy but such increase was not significant $(\mathrm{P}>0.05)$. Whereas, there was significant decrease $(\mathrm{P} \leq 0.05)$ in body weight of rabbits at 2 days postpartum $(2656 \pm 213.69 \mathrm{~g})$ compared to the rabbits at $30^{\text {th }}$ day of pregnancy $(3150 \pm 220.22 \mathrm{~g})$ (Figure 2).

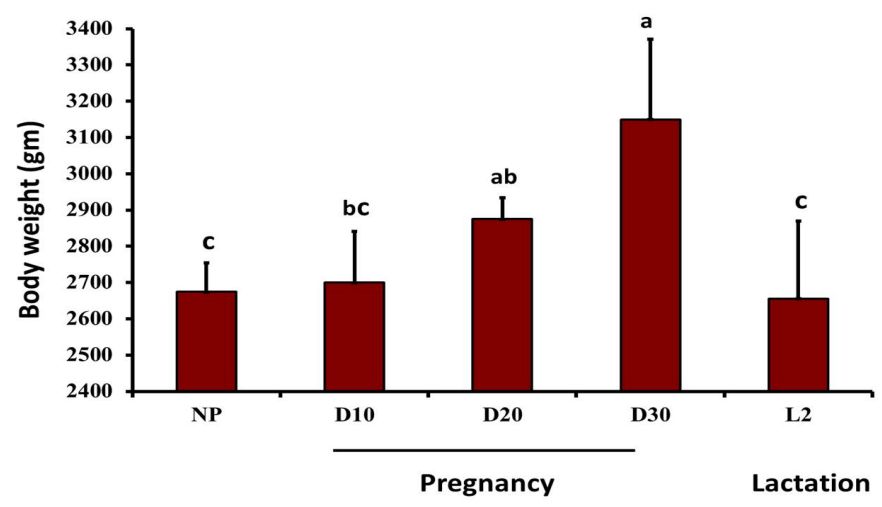

Figure 2. Body weight of rabbits during pregnancy and lactation. Body weights were estimated at $10^{\text {th }}, 20^{\text {th }}, 30^{\text {th }}$ day of pregnancy (D10, D20, and D30, respectively), lactation day 2 (L2), and non pregnant (NP) rabbits.

Different letters denote significant differences $(\mathrm{P} \leq 0.05)$. Data are expressed as means \pm S.E.M. of six animals each group

Pregnancy is the only normal physiologic process where body weight increases by $\sim 20$ percent and additional fat stores for lactation are deposited during the pregnancy period (Ueland \& Ueland, 1986). Gestational weight gain has been reported to be the primary and most important determinant of weight change from preconception to postpartum (postpartum weight change). Postpartum weight change is made up of the sum of gestational weight gain and the post-delivery weight loss (Gunderson \& Abrams, 2000).

Moreover, our study estimated the correlation between serum leptin level and body weight during pregnancy and postpartum in rabbits. The scatter graph (bivariate plot; Figure 3) gives a clear visual representation of the strength and direction of correlation between leptin and body weight. As seen in (Figure 3), the serum leptin was positively correlated with body weight $(0.670 ; \mathrm{P} \leq 0.05)$. This data was in harmony and confirmed those reported in human and rodent (Considine et al., 1996; Butte et al., 1997). Maffei et al. (1995) revealed that leptin may play an important role in regulating body weight by signaling the size of the adipose tissue mass.

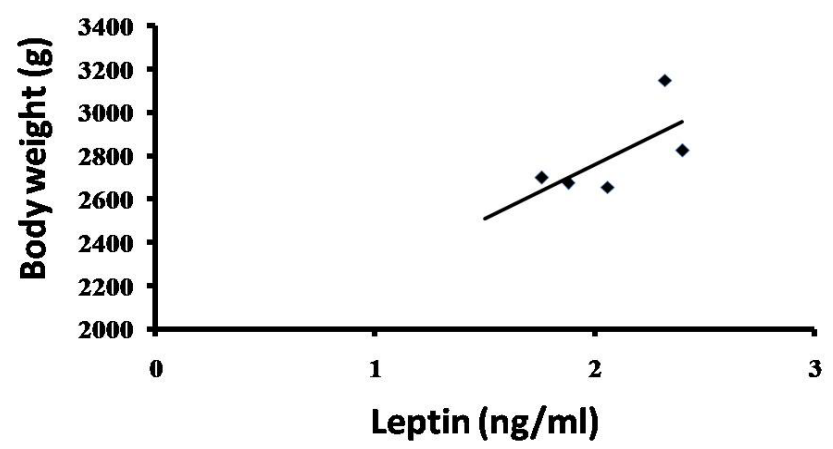

Figure 3. Correlation between serum circulating leptin levels and body weights in rabbits during pregnancy and lactation

In all mammals thus far examined, serum leptin levels increase during pregnancy and then decline shortly before or after parturition (Butte et al., 1997). The elevated maternal concentrations of leptin are not associated with decreased food intake or increased metabolic rate, as might be expected from known actions of leptin in non-pregnant mammals (Mounzih et al., 1998). Leptin resistance is a state in which there is an excess of serum 
leptin but the body does not effectively respond to these increased levels by reducing food intake or body weight (Frederich et al., 1995). This suggests that a pregnancy-associated state of partial leptin resistance may exist within the hypothalamus. Recently, resistance to the central effects of leptin during pregnancy and its effect on food intake has been verified in mice (Ladyman et al., 2012). Grattan et al. (2007) have demonstrated that intra cerebro-ventricular leptin is unable to suppress food intake in pregnant rats, as it does in non-pregnant animals. However, whether the suggested purpose of such resistance to leptin during pregnancy is to preferentially transport nutrients and/or promote fetal growth is not fully recognized. Tessier et al. (2013) has been reported that leptin resistance in healthy pregnancy seems to be central and beneficial for mobilizing energy stores to support adequate fetal growth. The central leptin resistance may act as a compensatory mechanism to meet the developing fetal energy needs. In later stages of a healthy pregnancy, central leptin resistance occurs to allow increased nutrient availability for the fetus (Tessier et al., 2013). These changes are physiologically appropriate, providing increased energy reserves to meet the high metabolic demands of fetal development and lactation.

(A)

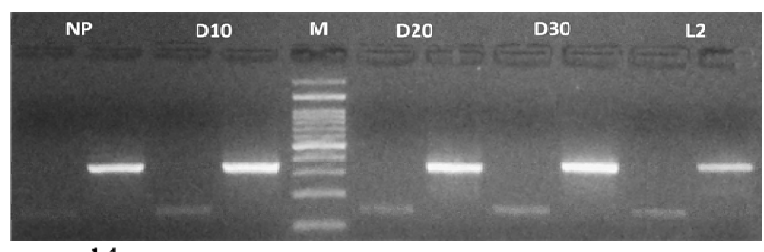

(B)

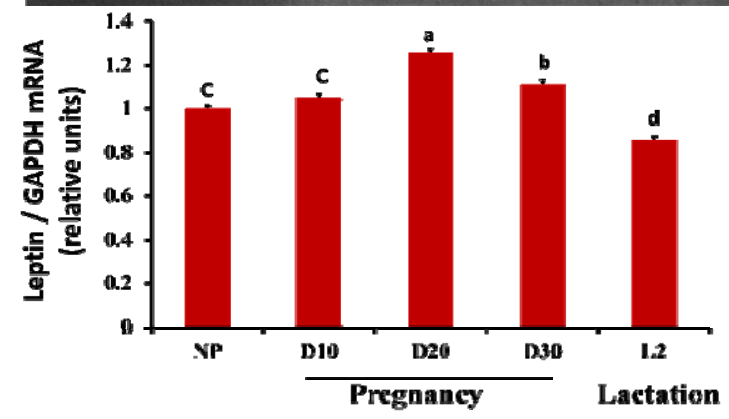

Figure 4. RT-PCR analysis of leptin in the rabbit maternal perirenal adipose tissue. (A) representative RT-PCR of leptin RNA expression in perirenal adipose tissue of rabbits during pregnancy and lactation. RNA from perirenal

adipose tissue of non pregnant (NP), pregnant day 10, 20, and 30 (D10, D20, and D30, respectively), and lactating day 2 (L2) rabbits, were reverse transcribed and amplified using the PCR method and specific primers for leptin. Eight microliters of the PCR reaction were run on 1.5\% agarose gel. A 100 base pair (bp) DNA ladder 100 bp DNA Ladder (Cat. No. M-214; Jena Bioscience GbH, Germany) was included as a reference for fragment size. GAPDH was used as a loading control. (B) Bar graph for the relative expression of leptin after normalization to GAPDH using the ImageJ program. Different letters denote significant differences $(\mathrm{P} \leq 0.05)$.

Data are expressed as means \pm S.E.M. of six animals each group

\subsection{Expression of Leptin RNA in the Adipose Tissue of Non Pregnant, Pregnant, \& Postpartum Rabbits}

To examine the leptin expression and its levels in perirenal adipose tissue of rabbits, RT-PCR was used to detect the RNA of leptin in perirenal adipose tissue of non pregnant, pregnant (pregnancy day 10, 20,30), and parturated (post-partum day 2) rabbits (Figure 4). As demonstrated in figure (Figure 4), leptin was expressed in all adipose tissue samples. The relative abundance of leptin RNA were significantly increased $(\mathrm{P} \leq 0.05)$ in rabbit maternal adipose at $10^{\text {th }}, 20^{\text {th }}$ and $30^{\text {th }}$ day of pregnancy as compared to the control non pregnant group (Figure 4). The highest expression level was observed at $20^{\text {th }}$ day of pregnancy and the lowest was noticed at the $10^{\text {th }}$ day of pregnancy (Figure 4). However, leptin RNA was significantly decreased at $2^{\text {nd }}$ day after parturition as compared to the control group $(\mathrm{P} \leq 0.05)$ (Figure 4). The elevated circulating leptin levels during pregnancy in rabbits, suggested that maternal leptin may play a role in maintenance of pregnancy and preparation for parturition and lactation.

Leptin is secreted by adipose cells, and its circulating concentration normally correlates with body adiposity (Considine et al., 1996). Leptin RNA is expressed in mice adipocytes, as shown using in situ hybridization, cell 
fractionation, and immunohistochemistry (Maffei et al., 1995). The plasma levels of leptin are highly correlated with adipose tissue mass and fall in both humans and mice after weight loss (Maffei et al., 1995).

Kronfeld-Schor et al. (2000) directly demonstrated that leptin secretion rates from mouse adipose tissue in vitro are decreased during early pregnancy and up-regulated during late pregnancy and lactation and these changes in leptin secretion rates in vitro paralleled those of circulating leptin in vivo during pregnancy. On the other hand, the increase in circulating leptin levels during mid to late pregnancy does not consistently correlate with adiposity in rats (Kawai et al., 1997; Amico et al., 1998), mice (Gavrilova et al., 1997; Tomimatsu et al., 1997), and humans (Butte et al., 1997). A clear increase in adipose leptin mRNA, however, has been observed during pregnancy in mice (Tomimatsu et al., 1997), suggesting that adipose tissue may be a major source of elevated serum leptin during pregnancy.

\subsection{Expression of Leptin RNA in the Placenta During Pregnancy in Rabbits}

The non adipose sources of leptin also might involve in the changes of circulating leptin during pregnancy. Several works have shown that in addition to adipose tissue, leptin is present in substantial amounts in the placentas of several species. Most available information describing placental leptin has been obtained from studies of rodents and humans. Our RT-PCR data proved the presence of RNA transcripts for leptin in the placenta of the pregnant rabbits (Figure 5). Even though no significant change in the placental leptin RNA expression levels was noticed among pregnant rabbits at $10^{\text {th }}(1.0 \pm 0.045), 20^{\text {th }}(0.91 \pm 0.058)$, and $30^{\text {th }}$ $(0.99 \pm 0.040)$ day of pregnancy (Figure 5).

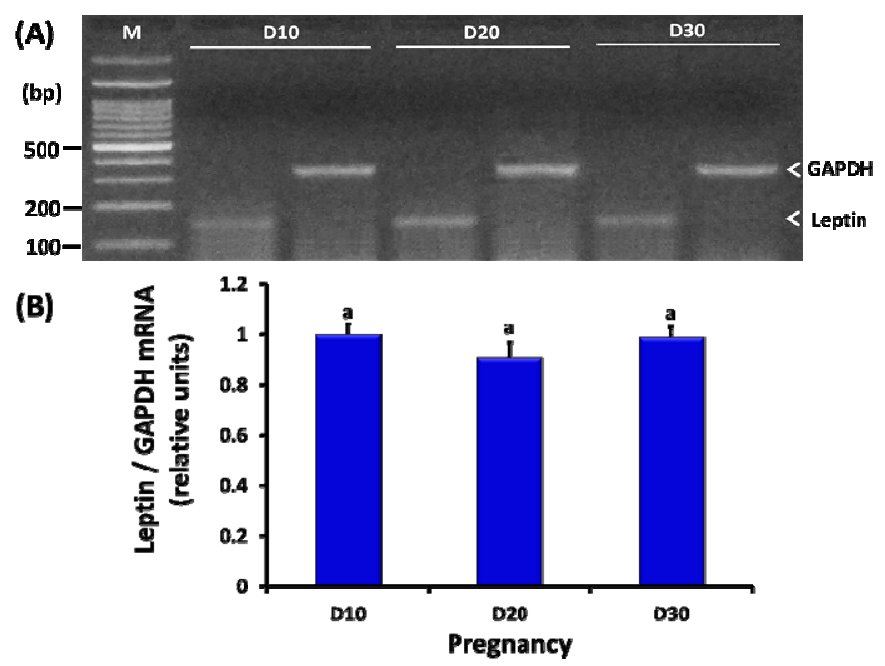

Figure 5. RT-PCR analysis of leptin in the rabbit maternal placenta. (A) representative RT-PCR of leptin RNA expression in planentas of rabbits during pregnancy and lactation. RNA from perirenal adipose tissue of non pregnant (NP), pregnant day 10, 20, and 30 (D10, D20, and D30, respectively), and lactating day 2 (L2) rabbits, were reverse transcribed and amplified using the PCR method and specific primers for leptin. Eight microliters of the PCR reaction were run on 1.5\% agarose gel. A 100 base pair (bp) DNA ladder 100 bp DNA Ladder (Cat. No. M-214; Jena Bioscience GbH, Germany) was included as a reference for fragment size. GAPDH was used as a loading control. (B) Bar graph for the relative expression of leptin after normalization to GAPDH using the ImageJ program. Different letters denote significant differences $(\mathrm{P} \leq 0.05)$. Data are expressed as means \pm S.E.M. of six animals each group

The human placenta contains substantial amounts of leptin mRNA and protein (Bi et al., 1997). Comparable amounts of immunoreactive leptin occur in the rodent placenta, although expression of rodent placental leptin mRNA appears to be much lower than in humans (Hoggard et al., 1997; Kawai et al., 1997; Tomimatsu et al., 1997; Terada et al., 1998). Importantly, the rodent placenta appears to contribute little, if any, leptin to the maternal circulation (Kawai et al., 1997; Hoggard et al., 2000). In agreement with our results (Figures 1 and 5), Gavrilova et al. (1997) have reported a dramatic increase of circulating leptin levels during mouse gestation with, however, no detectable increase in placental leptin production. On the other hand, Amico et al. (1998) revealed that as gestation advanced in rats, the serum leptin concentrations increased significantly and that was 
concomitant to a significant increase of placental leptin production. The benefit of placental leptin to the fetus may be for growth and angiogenesis, as leptin is considered an important growth factor in intrauterine and neonatal development (Hassink et al., 1997).

On the contrary with the suggestion that placenta provides a major contribution to circulating leptin during pregnancy, is that the plasma leptin levels do not return to baseline until several days after parturition and expulsion of the placenta (Gavrilova et al., 1997). One possible explanation for this is that adipose tissue continues to secrete leptin for a brief time after parturition (Kronfeld-Schor et al., 2000).

\subsection{Distribution and Expression Levels of Leptin RNA in the Various Fetal Tissues of Rabbits}

To date, the only indications that leptin may have a biologic function in the fetus is based on data obtained in mice and rats showing the expression of leptin receptor mRNA in several fetal tissues including cartilage, bone, lung, kidney, testes, and hypothalamus (Hoggard et al., 1997). To assess whether leptin is involved in the rabbit fetal growth and development, we have examined the distribution and relative expression levels of RNAs encoding leptin in various fetal tissues during rabbit pregnancy using RT-PCR analysis (Figure 6).

In the present study, RT-PCR verified the existence of RNAs encoding leptin in the whole rabbit fetus at day 10 of pregnancy and also in the brain, liver, perirenal adipose tissue, and bone of the rabbit fetus at $30^{\text {th }}$ day of pregnancy (Figure 6). Additionally, the relative abundance of leptin transcripts, as measured by the densitometric analysis, showed significant differences $(\mathrm{P} \leq 0.05)$ among the different regions of the fetal rabbit tissues (Figure 6). The leptin was most abundantly in the liver, at intermediate levels in adipose tissue and bone, and low level in the brain of fetuses on day $30^{\text {th }}$ of pregnancy (Figure 6).

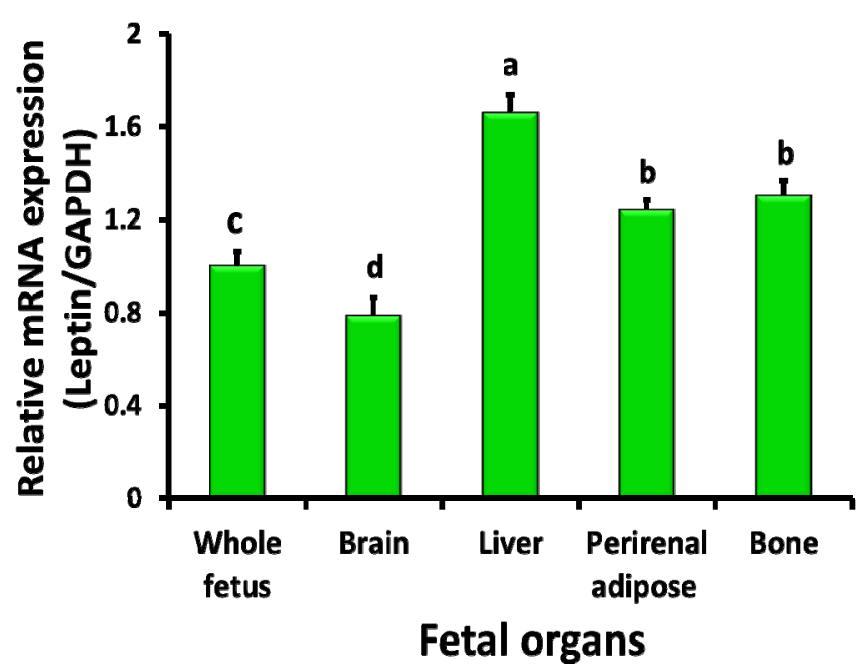

Figure 6. Detection of leptin expression in various rabbit fetal tissues by RT-PCR analysis. RNA from whole rabbit fetus at $10^{\text {th }}$ day of pregnancy as well as the rabbit brain, liver, perirenal adipose, and bone of fetus at $30^{\text {th }}$ day of pregnancy, were reverse transcribed and amplified using the PCR method and specific primers for leptin.

The bar graph represents the relative expression of leptin after normalization to GAPDH using the ImageJ program. Different letters denote significant differences $(\mathrm{P} \leq 0.05)$. Data are expressed as means \pm S.E.M. of six animals each group

On the contrary, the study by Hoggard et al. (1997) revealed that no leptin receptor (OB-R) gene expression either on the mRNA or protein level was identified in the heart, kidney, liver, adrenal, or pancreatic primordium of the 14.5-day postcoitus murine fetus. High levels of RNA expression for leptin and its receptor, however, were seen in the cartilage/bone, hair follicles, and lung as well as the leptomeninges and choroid plexus of the brain of the 14.5-day postcoitus murine fetus, suggesting a possible function of leptin as an autocrine or paracrine regulator in the fetus (Hoggard et al., 1997).

The expression of leptin in the rabbit fetal tissues (Figure 6) suggests that leptin may be involved in the growth and development of the fetus with one possible function being a fetal growth factor or a signal to the fetus of maternal energy status. Alternatively, fetal leptin could provide a signal to the mother of fetal growth and 
development. This implies a role for leptin in fetal bone and/or cartilage development that may be linked to its influence on hematopoiesis in the adult (Gainsford et al., 1996). The importance of SNAT (System A sodium dependant neutral amino acid transport) in fetal growth regulation has been well demonstrated (Jansson et al., 2003). Leptin has been shown to enhance SNAT activity, suggesting a role for leptin as a mediator of amino acid delivery to the fetus via the placenta (Jansson et al., 2003).

\subsection{Correlation Between Leptin Level and Steroids During Pregnancy and Lactation in Rabbits}

The "big two" of pregnancy hormones; estrogen and progesterone play vital roles during pregnancy, including triggering fetal development and common pregnancy symptoms. Estrogen and progesterone are two of the primary female sex hormones. The concentrations of estradiol $\left(\mathrm{E}_{2}\right)$ and progesterone in the serum of rabbits during the course of pregnancy have been determined by electrochemiluminescence immunoassay (ECLIA).

\subsubsection{Estrogen}

Estrogen influences various aspects of placental function and fetal development in humans and primates, and plays roles in the regulation of the onset of parturition, placental steroideogenesis, release of neuropeptides, release of glycoproteins, and leptin secretion (Chardonnens et al., 1999).

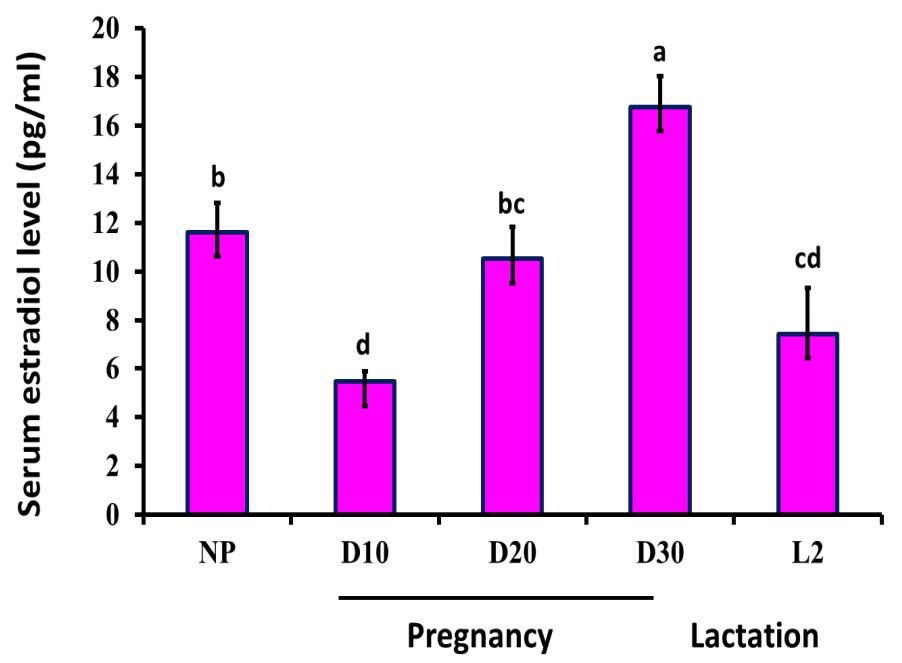

Figure 7. Serum circulating estradiol II $\left(\mathrm{E}_{2}\right)$ levels in rabbits during pregnancy and lactation. Estradiol II $\left(\mathrm{E}_{2}\right)$ concentrations $(\mathrm{pg} / \mathrm{ml})$ were measured in the serum samples obtained from rabbits at $10^{\text {th }}, 20^{\text {th }}, 30^{\text {th }}$ day of pregnancy (D10, D20, and D30, respectively), lactation day 2 (L2), and non pregnant (NP). Different letters denote significant differences $(\mathrm{P} \leq 0.05)$. Data are expressed as means \pm S.E.M. of six animals each group

Estradiol is present throughout pregnancy with a tendency to increase towards the end of gestation (Figure 7). Figure (7) revealed that the significant highest level of serum estradiol $\left(\mathrm{E}_{2}\right)$ was seen at $30^{\text {th }}$ day of pregnancy $(16.77 \pm 1.26 \mathrm{pg} / \mathrm{ml})$. On the other hand, significant decrease $(\mathrm{P} \leq 0.05)$ in serum $\mathrm{E}_{2}$ level was observed at $10^{\text {th }}$ day of pregnancy and at $2^{\text {nd }}$ day after parturition $(5.46 \pm 0.42 \mathrm{pg} / \mathrm{ml}$ and $7.40 \pm 1.95 \mathrm{pg} / \mathrm{ml}$, respectively) compared to its level in the non pregnant rabbits $(11.62 \pm 1.20 \mathrm{pg} / \mathrm{ml})$ as well as in rabbits at $20^{\text {th }}$ and $30^{\text {th }}$ of pregnancy $(10.53 \pm 1.30 \mathrm{pg} / \mathrm{ml}$ and $16.77 \pm 1.26 \mathrm{pg} / \mathrm{ml}$, respectively) (Figure 7).

Furthermore, there was a non-significant change in the serum estradiol level between rabbits at $20^{\text {th }}$ of pregnancy $(10.53 \pm 1.30 \mathrm{pg} / \mathrm{ml})$ and the non pregnant control group $(11.62 \pm 1.20 \mathrm{pg} / \mathrm{ml})$. Besides, there was a non-significant change in the serum estradiol level between rabbits at $10^{\text {th }}$ of pregnancy $(5.46 \pm 0.42 \mathrm{pg} / \mathrm{ml})$ and rabbits at $2^{\text {nd }}$ day after pregnancy $(7.40 \pm 1.95 \mathrm{pg} / \mathrm{ml})$ (Figure 7).

During pregnancy, the level of $E_{2}$ increases as a result of placental production. This increase of $E_{2}$ contributes to leptin production. Our results, as shown in Figure (8), detected a positive correlation between both serum leptin and estradiol levels in rabbits during pregnancy and lactation $(0.621 ; \mathrm{P} \leq 0.05)$. This means that when estradiol level increases in value, the leptin level also increases in value and vice versa.

It has been found that leptin pulsatility is positively and strongly correlated with $\mathrm{LH}$ and estrogen levels in normal cycling women (Licinio et al., 1998). Moreover, estrogen sensitizes leptin signaling (Ainslie et al., 2001). 
Ainslie et al. (2001) has showed that estrogen deficiency causes central leptin insensitivity and increased hypothalamic NPY. Furthermore, chronic estrogen withdrawal, as in ovariectomy in rodents and postmenopause in humans, causes leptin resistance, whereas estrogen replacement solves this problem (Ainslie et al., 2001). Estradiol administration enhances the expression of leptin mRNA transcripts and protein secretion by adipocytes, both in vitro and in vivo. Similarly, leptin expression in isolated rat adipocytes is inhibited by an estrogen receptor antagonist, and diminution of leptin expression in white adipose tissue in rats following ovariectomy is reverted with $\mathrm{E}_{2}$ administration (Henson \& Castracane, 2006).

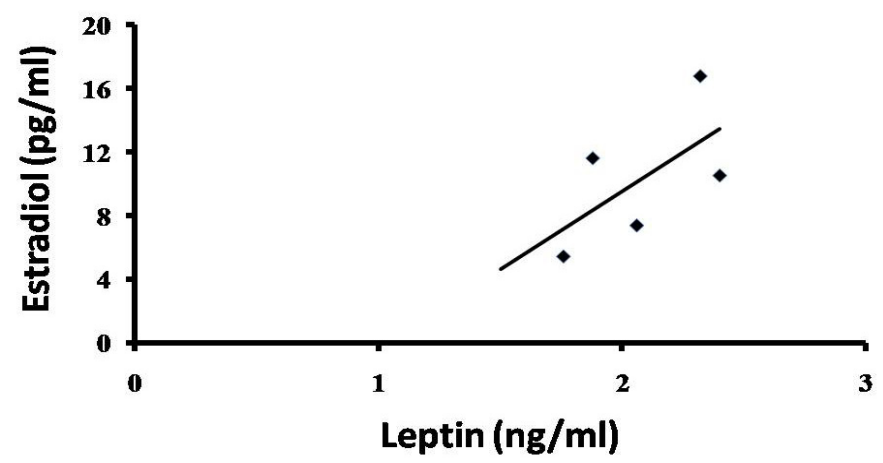

Figure 8. Correlation between serum circulating leptin levels and serum circulating estrogen levels in rabbits during pregnancy and lactation

\subsubsection{Progesterone}

Progesterone is produced by the ovary which is essential for the maintenance of pregnancy for 30-32 days in rabbits and is crucial for keeping the uterus in a quiescent state to prevent premature onset of labor.

The present study showed that serum progesterone levels were significantly increased $(\mathrm{P} \leq 0.05)$ in the rabbits at $10^{\text {th }}, 20^{\text {th }}$, and $30^{\text {th }}$ day of pregnancy $(9.86 \pm 1.93 \mathrm{ng} / \mathrm{ml}, 5.25 \pm 0.53 \mathrm{ng} / \mathrm{ml}$, and $4.10 \pm 1.51 \mathrm{ng} / \mathrm{ml}$, respectively) in comparison to the non-pregnant control group and 2 days after parturition $(2.40 \pm 0.73 \mathrm{ng} / \mathrm{ml}$, and $1.58 \pm 0.05$ $\mathrm{ng} / \mathrm{ml}$, respectively) (Figure 9).

Moreover, we found that the serum progesterone level was significantly increases $(\mathrm{P} \leq 0.05)$ in rabbits at $10^{\text {th }}$ day of pregnancy $(9.86 \pm 1.93 \mathrm{ng} / \mathrm{ml})$ when compared to the other groups (Figure 9). Whereas, no significant difference was observed in the serum progesterone level at $20^{\text {th }}$ day $(5.25 \pm 0.53 \mathrm{ng} / \mathrm{ml})$ and $30^{\text {th }}$ day of pregnancy $(4.10 \pm 1.51 \mathrm{ng} / \mathrm{ml})$ in rabbits (Figure 9).

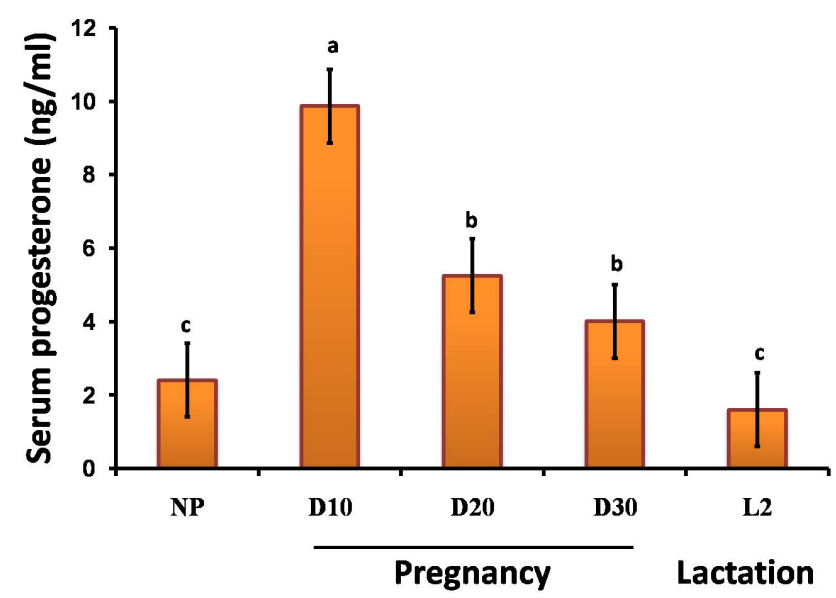

Figure 9. Serum circulating progesterone levels in rabbits during pregnancy and lactation. Progesterone concentrations $(\mathrm{ng} / \mathrm{ml})$ were measured in the serum samples obtained from rabbits at $10^{\text {th }}, 20^{\text {th }}, 30^{\text {th }}$ day of pregnancy (D10, D20, and D30, respectively), lactation day 2 (L2), and non pregnant (NP). Different letters denote significant differences $(\mathrm{P} \leq 0.05)$. Data are expressed as means \pm S.E.M. of six animals each group 


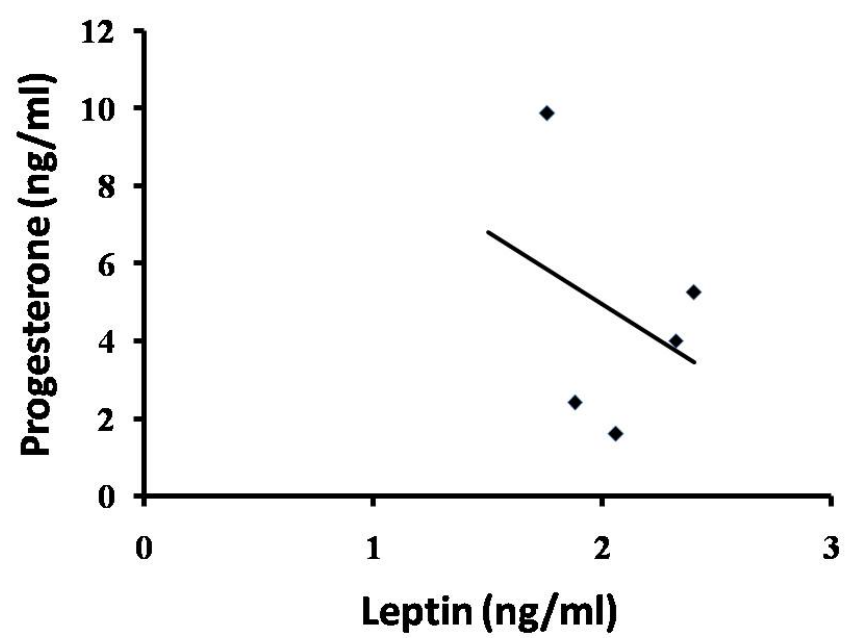

Figure 10. Correlation between serum circulating leptin levels and serum circulating progesterone levels in rabbits

In late pregnancy when placental progesterone production is at its height, progesterone has been reported to inhibit leptin secretion by human placental cells in culture (Coya et al., 2005). On the other hand, leptin always led to an inhibitory effect on progesterone secretion (Cameo et al., 2003).

The negative correlation found between serum leptin and progesterone levels in rabbits $(-0.33 ; \mathrm{P} \leq 0.05)$ (Figure 10) means that during pregnancy and lactation when the leptin level increases in value, the progesterone level decreases in value. Our findings are in agreement with an inhibitory effect of leptin on progesterone secretion found in other tissues, such as rat granulosa cells (Spicer et al., 2000) and human term placental trophoblast cells (Cameo et al., 2003).

\section{Conclusion}

To the best of our knowledge this is the first report on the distribution and expression levels of leptin in rabbit maternal adipose tissue and placenta as well as in different fetal tissues including; brain, liver, bone, and perirenal adipose tissue during pregnancy. Moreover, our study proved that leptin has positive correlations with body weight and estrogen and negative correlation with progesterone in pregnant and postpartum rabbits. Results of our study imply a fundamental role of leptin in the maintenance of pregnancy and preparation for lactation. The present data strongly reinforce the idea that circulating leptin levels may provide a growth-promoting signal for fetal development during late pregnancy. Overall, the present work supports the importance of leptin in reproductive physiology and fetal development. Although great progress has been made in the last few years towards understanding the physiological roles of leptin, several fundamental questions still need to be answered.

\section{References}

Ainslie, D. A., Morris, M. J., Wittert, G., Turnbull H., Proietto J., \& Thorburn, A. W. (2001). Estrogen deficiency causes central leptin insensitivity and increased hypothalamic neuropeptide Y. Int J Obes Relat Metab Disord, 25, 1680-1688.

Amico, J. A., Thomas, A., Crowley, R. S., \& Burmeister, L. A. (1998). Concentrations of leptin in the serum of pregnant, lactating, and cycling rats and of leptin messenger ribonucleic acid in rat placental tissue. Life Sci, 63, 1387-1395.

Bi, S., Gavrilova, O., Gong, D. W., Mason, M. M., \& Reitman, M. (1997). Identification of a placental enhancer for the human leptin gene. J Biol Chem, 272(48), 30583-30588.

Butte, N. F., Hopkinson, J. M., \& Nicolson, M. A. (1997). Leptin in human reproduction: serum leptin levels in pregnant and lactating women. J Clin Endocrinol Metab, 82, 585-589.

Cameo, P., Bischof, P., \& Calvo, J. C. (2003). Effect of leptin on progesterone, human chorionic gonadotropin, and interleukin-6 secretion by human term trophoblast cells in culture. Biol Reprod, 68(2), 472-477. http://dx.doi.org/ 10.1095/biolreprod.102.006122 
Chardonnens, D., Cameo, P., Aubert, M. L., Pralong, F. P., Islami, D, Campana, A, ... Bischof, P. (1999). Modulation of human cytotrophoblastic leptin secretion by interleukin-1alpha and 17beta-oestradiol and it effect on HCG secretion. Mol Hum Reprod, 5, 1077-1082. http://dx.doi.org/ 10.1093/molehr/5.11.1077

Considine, R. V., Sinha, M. K., Heiman, M. L., Kriauciunas, A., Stephens, T. W., Nyce, M. R., ... Caro, J. F. (1996). Serum immunoreactive-leptin concentrations in normal-weight and obese humans. $N$ Engl J Med, 334(5), 292-295. http://dx.doi.org/10.1056/NEJM199602013340503

Coya, R., Martul, P., Algorta, J., Aniel-Quiroga, M. A., Busturia, M. A., \& Señarís, R. (2005). Progesterone and human placental lactogen inhibit leptin secretion on cultured trophoblast cells from human placentas at term. Gynecol. Endocrinol, 21(1), 27-32. http://dx.doi.org/10.1080/09513590500099305

Cumin, F., Baum, H. P., \& Levens, N. (1996). Leptin is cleared from the circulation primarily by the kidney. Int $J$ Obes Relat Metab Disord, 20(12), 1120-1126.

Cunningham, M. J., Clifton, D. K., \& Steiner, R. A. (1999). Leptin's Actions on the Reproductive Axis: Perspectives and Mechanisms. Biology of reproduction, 60, 216-222. http://dx.doi.org/10.1095/ biolreprod60.2.216

Gainsford, T., Willson, T. A., Metcalf, D., Handman, E., McFarlane, C., Ng, A., ... Hilton, D. (1996). Leptin can induce proliferation, differentiation, and functional activation of hemopoietic cells. J Proc Natl Acad Sci USA, 93, 14564-14568.

Gavrilova, O., Barr, V., Marcus-Samuels, B., \& Reitman, M. (1997). Hyperleptinemia of pregnancy associated with the appearance of a circulating form of the leptin receptor. J Biol Chem, 272, 30546-30551. http://dx.doi.org/10.1074/jbc.272.48.30546

Gonzalez, R. R., \& Leavis, P. C. (2003). A peptide derived from the human leptin molecule is a potent inhibitor of the leptin receptor function in rabbit endometrial cells. Endocrine, 21(2), 185-95. http://dx.doi.org/10.1385/ENDO:21:2:185

Grattan, D. R., Ladyman, S. R., \& Augustine, R. A. (2007). Hormonal induction of leptin resistance during pregnancy. Physiol Behav, 91(4), 366-374. http://dx.doi.org/10.1016/j.physbeh.2007.04.005

Gunderson, E. P., \& Abrams, B. (2000). Epidemiology of gestational weight gain and body weight changes after pregnancy. Epidemiol Rev, 22(2), 261-274.

Hassink, S. G., deLancey, E., Sheslow, D. V., Smith-Kirwin, S. M., O'Connor, D. M., Considine, R. V., ... Funanage, V. L. (1997). Placental leptin: an important new growth factor in intrauterine and neonatal development? Pediatrics, 100, E1-E6. http://dx.doi.org/10.1542/peds.100.1.e1

Henson, M. C., \& Castracane, V. D. (2006). Leptin in pregnancy: an update. Biol Reprod, 74(2), 218-29. http://dx.doi.org/10.1095/biolreprod.105.045120

Herrera, E., Lasunción, M. A., Huerta, L., \& Martín-Hidalgo, A. (2000). Plasma leptin levels in rat mother and offspring during pregnancy and lactation. Biol Neonate, 78(4), 315-20. http://dx.doi.org/10.1159/ 000014286

Hoggard, N., Hunter, L., Duncan, J. S., Williams, L. M., Trayhurn, P., \& Mercer, J. G. (1997). Leptin and leptin receptor mRNA and protein expression in the murine fetus and placenta. Proc Natl Acad Sci US A, 94, 11073-11078. http://dx.doi.org/10.1073/pnas.94.20.11073

Jansson, N., Greenwood, S. L., Johansson, B. R., Powell, T. L., \& Jansson, T. (2003). Leptin stimulates the activity of the system A amino acid transporter in human placental villous fragents. $J$ Clin Endocrinol Metab, 88, 1205-1211. http://dx.doi.org/http://dx.doi.org/10.1210/jc.2002-021332

Kawai, M., Yamaguchi, M., Murakami, T., Shima, K., Murata, Y., \& Kishi, K. (1997). The placenta is not the main source of leptin production in pregnant rat: gestational profile of leptin in plasma and adipose tissues. Biochem Biophys Res Commun, 240, 798-802. http://dx.doi.org/10.1006/bbrc.1997.7750

Koch, E., Hue-Beauvais, C., Galio, L., Solomon, G., Gertler, A., Révillon, F., ... Charlier, M. (2013). Leptin gene in rabbit: cloning and expression in mammary epithelial cells during pregnancy and lactation. Physiol Genomics, 45(15), 645-652. http://dx.doi.org/10.1152/physiolgenomics.00020.2013

Kronfeld-Schor, N., Zhao, J., Silvia, B. A., Bicer, E., Mathews, P. T., Urban, R., ... Widmaier E. P. (2000). Steroid-dependent up-regulation of adipose leptin secretion in vitro during pregnancy in mice. Biol Reprod, 63, 274-280. http://dx.doi.org/10.1095/biolreprod63.1.274 
Ladyman, S. R., Fieldwick, D. M., \& Grattan, D. R. (2012). Suppression of leptin-induced hypothalamic JAK/STAT signalling and feeding response during pregnancy in the mouse. Reproduction, 144, 83-90. http://dx.doi.org/10.1530/REP-12-0112

Licinio J., Negrao A. B., Mantzoros, C., Kaklamani, V., Wong, M. L., Bongiorno, P. B., ... Gold, P. W. (1998). Synchronicity of frequently sampled, 24-h concentrations of circulating leptin, luteinizing hormone, and estradiol in healthy women. Proc Natl Acad Sci USA, 95, 2541-2546.

Maffei, M., Halaas, J., Ravussin, E., Pratley, R. E., Lee, G. H., Zhang, Y., ... Friedman, J. M. (1995). Leptin levels in human and rodent: measurement of plasma leptin and ob RNA in obese and weight-reduced subjects. Nat Med, 1(11), 1155-1161.

Mounzih, K., Qiu, J., Ewart-Toland, A., \& Chehab, F. F. (1998). Leptin is not necessary for gestation and parturition but regulates maternal nutrition via a leptin resistance state. Endocrinology, 139(12), 5259-5262.

Seeber, R. M., Smith, J. T., \& Waddell, B. J. (2002). Plasma leptin-binding activity and hypothalamic leptin receptor expression during pregnancy and lactation in the rat. Biol Reprod, 66(6), 1762-1767. http://dx.doi.org/10.1095/biolreprod66.6.1762

Spicer, L. J., Chamberlain, C. S., \& Francisco, C. C. (2000). Ovarian action of leptin: effects on insulin-like growth factor-I-stimulated function of granulosa and thecal cells. Endocrine, 12, 53-59. http://dx.doi.org/10.1385/ENDO:12:1:53

Terada, Y., Yamakawa, K., Sugaya, A., \& Toyoda, N. (1998). Serum leptin levels do not rise during pregnancy in age-matched rats. Biochem Biophys Res Commun, 253(3), 841-844. http://dx.doi.org/10.1006/bbrc.1998.9861

Tessier, D. R., Ferraro, Z. M., \& Gruslin, A. ( 2013). Role of leptin in pregnancy: consequences of maternal obesity. Placenta, 34(3), 205-211. http://dx.doi.org/http://dx.doi.org/10.1016/j.placenta.2012.11.035

Tomimatsu, T., Yamaguchi, M., Murakami, T., Ogura, K., Sakata, M., Mitsuda, N., ... Murata, Y. (1997). Increase of mouse leptin production by adipose tissue after midpregnancy: gestational profile of serum leptin concentration. Biochem Biophys Res Commun, 240, 213-215. http://dx.doi.org/10.1006/bbrc.1997.7638

Ueland, K., \& Ueland, F. R. (1986). Physiologic adaptations to pregnancy. In R. A. Knuppel, \& J. E. Drukker (Eds.), High-risk pregnancy, a team approach (pp. 148-172). Philadelphia, PA: Saunders.

Zerani, M., Boiti, C., Zampini, D., Brecchia, G., Dall'Aglio, C., Ceccarelli, P., \& Gobbetti, A. (2004). Ob receptor in rabbit ovary and leptin in vitro regulation of corpora lutea. $J$ Endocrinol, 183(2), 279-288. http://dx.doi.org/10.1677/joe.1.05507

Zhang, Y., Proenca, R., Maffei, M., Barone, M., Leopold, L., \& Friedman, J. M. (1994). Positional cloning of the mouse obese gene and its human homologue. Nature, 372, 425- 432. http://dx.doi.org/10.1038/372425a0

Zhao, S. P., \& Wu, Z. H. (2005). Atorvastatin reduces serum leptin concentration in hypercholesterolemic rabbits. Clin Chim Acta, 360(1-2), 133-140. http://dx.doi.org/10.1016/j.cccn.2005.04.021

\section{Copyrights}

Copyright for this article is retained by the author(s), with first publication rights granted to the journal.

This is an open-access article distributed under the terms and conditions of the Creative Commons Attribution license (http://creativecommons.org/licenses/by/3.0/). 